\title{
An Interview with Douglas Robinson
}

ADITYA KUMAR PANDA

Douglas Robinson (hereafter DR) is a Chair Professor of English at Hong Kong Baptist University, Hong Kong. He is a well-known scholar in the field of Translation Studies. Aditya Kumar Panda, (hereafter AKP) an assistant editor of Translation Today, interviews Douglas Robinson.

AKP: George Steiner's After Babel influenced you in the early years of your university life that you had admitted in an interview. How did it impact upon you?

DR: I had been translating for almost ten years when I happened upon After Babel in our university library (in Tampere, Finland). I had been thinking that I might like to read and write about translation, and wondered what had been written about it - and after getting frustrated with a lot of pedestrian scholarship on our library shelves, I found Steiner's book, and read it avidly, cover to cover. Then I bought it, and read it again, and marked it up. It was thrilling to me! Steiner gave me a useful overview of the translation scholarship that he himself valued-especially the German Romantic tradition - and that struck a chord with me as well; he was a sensitive reader of literature and philosophy, and brought to his task a hermeneutical sensibility, which I immediately embraced; but what I especially valued was the force of his personality, which exploded off the page. I took him on as my mentor in the field of Translation Studies, as I was just beginning to explore it.

AKP: Before The Translator's Turn, you wrote a bilingual monograph that you did not publish. Later, you transformed it 
into The Translator's Turn. How did you write The Translator's Turn? How was it received at that time, when the field of Translation Studies was still evolving?

DR: I think I would say I didn't so much "transform" that bilingual monograph, "Kääntämisen kääntöpiirit/The Tropics of Translation," as cannibalize it. The Translator's Turn was a very different kind of book. "KK/TT" was a stylistic experiment: I wrote it in English, then translated it into Finnish, and while I was translating it, I kept rethinking my arguments for a Finnish audience, which ended up pulling the arguments in new directions. Sometimes the Finnish would veer off from the English for 8-10 pages at a time, before I was able to bring it back into alignment with the English. I used the tensions between the English and the Finnish to comment on the nature of translation too-a kind of running metacommentary. None of that was possible once I decided to get rid of the Finnish and create The Translator's Turn. So that felt like a loss.

Also, the tropics of translation formed the whole of "KK/TT," and only the second half of The Translator's Turn. I had to work up the somatics (Chapter 1) and dialogics (Chapter 2) from scratch. That was exciting, of course: I'd been working on the somatics of language for several years by 1988, the year when I began writing Turn, had given two conference talks on it, but had never written up my ideas; and I had been exposed to Bakhtin in my Ph.D. program 6-7 years earlier, and become obsessed with him (and still am). Rather than just doing Bakhtin in Chapter 2, though, I decided I would work up to him, starting with Augustine in the last three sections of Chapter 1, and moving through Luther, Goethe, and Buber before letting Bakhtin burst onto the scene. That became my first foray into the history of thinking about translation; at 
the time I was also teaching that history in the Translation Studies Department at the University of Tampere, and, since there was no anthology available back then, I spent a week at the Library of Congress in Washington, D.C., one summer collecting photocopies. That eventually became my anthology, Western Translation Theory from Herodotus to Nietzsche, which I wrote in 1992-1993, but didn't manage to publish until 1997.

I should say, too, that I had quite radical ideas about academic writing in the mid-1980s-I wanted to revolutionize academic discourse, with numbered notes, epistolary form, dialogue, etc.-but it became increasingly clear that my experiments were simply not publishable, and, with considerable reluctance, I began to move back in the direction of more conventional writing styles. The Translator's Turn was my first "sellout" - that's how it felt back then-my first attempt to write in a somewhat innovative voice that still looked and felt more or less like traditional academic discourse. The resulting popularizing tone, and maybe the insouciance, or even flippancy, was a big part of what irritated the major established translation scholars at the time-but also what made it a big hit among younger, more radical, and perhaps more peripheral translator-scholars. I heard stories about people touting the book excitedly at conferences as the only translation theory anyone would ever need to read; I also heard of people summarizing it as saying "translators don't need to think, they only need to feel." That was a bit frustrating! (I write about this in a recent article: "The Somatics of Tone and the Tone of Somatics: The Translator's Turn Revisited." TIS: Translation and Interpreting Studies 10.2: 299-319.) 
AKP: You develop ideas from many disciplines. You have used ideas from Philosophy and Neurology in your Somatic Theory that has a certain degree of intricacies. You have also got theoretical somatic underpinnings in Confucian thoughts. How is it that the Chinese scholars understand your Somatic theory better than the Westerners do?

DR: When I moved to Hong Kong in 2010, I wanted to familiarize myself with Chinese philosophy, and someone recommended I begin with Mengzi (Mencius). So I got D.C. Lau's 1970 translation and began reading, and was astonished to find that he knew things about somatic theory that I had been struggling to articulate for more than two decades. So I immersed myself in it, reading as many translations as I could find and laboriously comparing the key passages with the Chinese original - and the more I learned, the more excited I became. This truly was transformative! As I began talking to Chinese audiences about my somatic theory, and building bridges to Mengzi (and later Laozi), I found that they had absolutely no difficulty understanding me. In the West, my talks on the somatics of language and translation always tended to be met with stunned silence; my Chinese audiences engaged me intelligently from the start. Why? I wondered. Gradually I figured out why: 心 xin, which is a pictographic representation of the human heart, is also commonly translated (by Chinese people with good English) as "mind." Mengzi says that the heart thinks - in the sense that the heart guides the mind in decision-making. The heart-becoming-mind (as I came to translate it) is the source of all ethical growth in Chinese culture. As a result, Chinese people are not inclined to think of feeling as a random bodily disturbance that distorts thought. Feeling occupies a respected position in the philosophical underpinnings of Chinese culture. (The only way a Chinese person might be inclined to assume that my discussion of 
somatics in The Translator's Turn meant that the translator only needs to feel, not think, would be if s/he had been raised in the West.)

AKP: You discussed a new approach to translation that draws neither from Linguistics nor from literary studies in your introduction to Translation and Empire. Why do you think the approaches from Linguistics and Literary studies are inadequate in the study of translation? How far is the new approach arising out of Anthropology, Ethnography and Colonial Studies adequate to study translation?

DR: I'm not sure I would draw stable boundaries between approaches that are "adequate" and "inadequate" to the study of translation. If you're interested in textual equivalence, a linguistic approach might well be adequate. If you're interested in literary or scholarly history, a literary approach might be adequate. But obviously if you're studying the role translation has played in the history of empire, you need something more. (My scholarship tends to be problem-driven: whatever is needed to explore a given problem is fair game. I don't set disciplinary boundaries in advance.) And the way that worked was that Anthony Pym asked me to write the book as a userfriendly introduction to postcolonial translation theory-which meant covering the emergence of postcolonial translation studies out of cultural anthropology and ethnography.

AKP: The study of translation is no longer limited to the age-old debate of 'word for word' or 'sense for sense' translation or whether it is faithful or not. The later part of the 20th century witnessed the emerging critical approaches to what a translation is. Translation is becoming a phenomenon more of socio-cultural forces. Starting from Zohar's Polysystem theory to Lefevere's concept of translation as 
rewriting has redefined what a translation is. You have also said in Who Translates?: Translator Subjectivities Beyond Reason that translating is writing. Could you limit the boundary of what a translation is? If not, how would you define it?

DR: Again, I'm not particularly interested in setting boundaries. I'm much more interested in crossing them. For the three decades of my TS career to date, I've been drawn to Gideon Toury's pragmatic definition of translation as whatever people call a translation. In my most recent book, Translationality (Routledge, 2017), I track what I call "translationality" through a convoluted literary history involving adaptation, rewriting, translation, pretend translation, and so on, as a dynamic of historical change. Instead of starting with things that stay the same, I say, let's start with things that change-and allow ourselves to notice that everything changes.

AKP: To study a translation, one must translate first, to teach about translation one must translate first. As you have rightly said in the introductory chapter of Becoming $a$ Translator that 'there is no substitute for practical experience - to learn how to translate one must translate, translate, translate'. How much of theory is required in training a translator? What should be the pedagogic method in a translators' training programme?

DR: I don't have answers to those two questions. I've never been trained as a translator! And I only began thinking theoretically about translation, as I mentioned earlier, after I'd been translating for ten years. I've taught translation theory to undergraduates several times-I teach it here in Hong Kongand one of the questions I keep getting my students to think 
about, and talk about, is how useful this is. Each is required to do a presentation applying a given theory to a practical translation situation, and to involve the other students in deciding about its value. I do think that theory can be a useful shortcut-it can help novice translators broaden their understanding of what translation is, early on, so that they don't just lock into a single narrow conception (like "translation is an exact reproduction of the source text," which is true of technical translation but not of advertising translation, etc.) and find themselves unable to respond flexibly to job offers outside their comfort zone.

I would say also, of course, that university study should always consist of both theory and practice - testing practice with theory, and testing theory with practice, in a kind of virtuous cycle. That means that, regardless of any practical use to which future translators might put theory, it has an important place in any university TS curriculum. What professional translators will need to know on the job is not the only consideration.

AKP: A translator, a socio-cultural entity, cannot control his act of translation as only he is not translating but there are factors that may influence him/her in the process of translation. How would you view a translator's subjectivity in the process of translation?

DR: I'm not sure it's possible to generalize. My book Who Translates? is subtitled Translator Subjectivities Beyond Reason for a good reason! I'm not even sure I know my own translator-subjectivity. I like thinking about it, and I built Becoming a Translator around a series of attempts to trigger and organize memory and creativity, through dramatization and visualization; probably my assumptions about the 
translator's subjectivity figure into everything I write about translation. But I'm still not sure about it.

AKP: Why is Venuti's conception of foreignizing translation inadequate? Could you please explain the 'friendly amendments' to Venuti's concept that you have proposed in your book Translation and the Problem of Sway?

DR: That's too big a subject! I've been picking at foreignization for twenty years, over and over. Translation and the Problem of Sway was indeed my first foray into a rethinking of foreignization, through the study of ostranenie/Verfremdung that I did in Estrangement and the Somatics of Literature (2008); but then came Schleiermacher's Icoses (2013), Critical Translation Studies (2017: 10-11), and Aleksis Kivi and/as World Literature (2017: 156-60). I did a quickie summary of my various takes on foreignization in my new book, Translationality (2017: 144-48); perhaps readers can read that instead?

AKP: What is the Dao of Translation? How do you apply Daoist thoughts to the study of translation?

DR: Well, that was the question! I thought there must be a way, but wasn't sure what it would be. The book (The Dao of Translation: An East-West Dialogue, 2015) had its beginning in an endnote I wrote in Semiotranslating Peirce (2016) about Ritva Hartama-Heinonen's 2008 dissertation on abductive translation: the footnote first swelled to ten pages, then to twenty, and just kept on growing until I had to split it off and turn it into a separate book. In that original footnote I observed that Hartama-Heinonen's mystical notion that the translator should not translate - should not do anything at all — but rather should sit back and let the sign translate itself was a bit like the 
Daoist notion of 無爲 wuwei, which literally means "without acting." I knew that Laozi didn't actually mean "without acting"; I'd read about the concept, and his actual notion of minimal interference; but I didn't really know enough about it to do anything with this association I drew between HartamaHeinonen's mystical abduction and Daoism - especially given that Hartama-Heinonen gave no explicit sign of knowing or caring about Daoism. She called her approach Peircean and Romantic, and in fact it seemed more Romantic than Peircean to me; and I knew that the German and English Romantics, and the American Transcendentalists (who influenced Peirce) were all avid readers of the ancient Confucian and Daoist classics. But I didn't know what to do with all that until I read Roger Ames and David Hall's "philosophical translation" of the 道德經 Daodejing, in which they claimed, persuasively, that what they called the "wu forms"-wuwei, but also 無知 wuzhi (not knowing), 無欲 wuyu (not desiring), 無心 wuxin "not feeling"-were not so much about not doing a thing, as they were about the habitualization of the doing of that thing, so that it felt as if one was not doing it.

Then the idea came to me: Hartama-Heinonen attacked my use of Peirce in Becoming a Translator, accusing me of celebrating the "hardening" of the translator's professional habits; but in fact what the translator's habit achieved was precisely that wuwei that she seemed (without the word) to be celebrating. Because the translator's skill is habitualized, it feels as if s/he is not translating - as if the text were somehow translating itself. So that became the argument in the bookfleshed out with more readings of Peirce on habit and the commends, Saussure from his posthumous notes, Bourdieu, and so on. 
AKP: One could witness many turns in the study of translation like linguistic, pragmatic and cultural. You talked about an inter-civilizational turn in the study of translation. Could you please explain about this turn?

DR: It's a response to the seething I've begun to feel in Western translation scholars, and even in one Chinese colleague, about this whole issue of Eurocentrism-whether Translation Studies as a field is Eurocentric. I think it's pretty obvious that it is, or has been; but the idea agitates a lot of people. What I wanted to suggest in Exorcising Translation: Towards an Intercivilizational Turn, was that this tension around Eurocentrism vs. Sinocentrism, etc., is actually the birth pangs of a new Turn, namely, one that recognizes and embraces the global differences and dialogues that (ideally should) make up the field (or any field). Drawing on Sakai Naoki's notion of cofiguration, I argue that Orientalism and Occidentalism, Eurocentrism and other -centrisms, are actually not so much "centred" anywhere as they are cofigurative interactions that work across power differentials to constitute civilizational "identities." The fact that the West has had more global power than the East for the last few centuries has made the various cofigurative regimes feel like a -centrism; but the West is not really the center. It's just (so far) the stronger partner in a dialogue, or a lot of dialogues.

AKP: How do you visualize the future of Translation Studies as an academic discipline?

DR: No idea, sorry. I have no crystal ball, and am not in the habit of predicting the future! 